\title{
THE SPECIFIC OF HOMESCHOOLING AS EDUCATIONAL ALTERNATIVE
}

\author{
Camelia Nadia BRAN, Ph.D. \\ „Aurel Vaicu" University of Arad \\ AncaSZEMAN, \\ Teacher at Paulis Kindergarten \\ camelia.bran@uav.ro
}

\begin{abstract}
More and more parents consider education at home, homeschooling, as a solution to the crisis of the educational system from Romania. In our country, there are few scientific studies analysis of the impact of this alternative on cognitive acquisitions and the development of personality traits of children. The study proposed by us, carried out in the spring 2017, had as its primary objective the analysis of how homeschooling is practiced and carried out in families in our country, especially due to the fact that, in Romania, this educational alternative is not legalized. One of the methods of data collection were the online questionnaire. We have noticed that parents who already practice this system education face the prejudices of those around, most of the time, not even supporting the family or close friends. Sometimes due to this system of thinking, parents do not even dare to say they are educating themselves their own children, fearing that they will be judged. The legalization of this system and putting it "in the light" of the scientific approach would be just for the benefit of the children.
\end{abstract}

Keywords:home schooling, educational alternative, questionnaire, learning program

\section{Theoretical premises}

Noah Webster claimed that all governments originated in families and, if we had neglecting this, it would hardly be believed that they would still exist in society. He said that the foundation of all free governance and of all social order must be put on the family and on discipline of young people. (Noah Webster, 1828)

Education at home started in the 1600s but we can not know exactly. But what we know for certain is that this education was done under the guidance of a parent or a tutor because there were no public schools. Later, when traditional schools appeared, the idea of education at home seemed something out of the ordinary, strange, unusual. In 2001, the notion of home education began to reach the ears of as many as possible Romanians and, in 
2002, the Home-schooling Romania Association was initiating steps in order to legalize home education.

Parents practicing home-based education in Romania have enrolled their children at schools from abroad (umbrella schools), which sustain home schooling approach, from whom they can get enrolment number, curriculum and diplomas. These schools issue diplomas and enrolment sheets online or by mail, following tests, documents that are recognized by the Romanian state. They organize also the international baccalaureate that is approved and recognized in Romania as well. In Europe, centers have been set up where students can be examined for general knowledge in English language.

In addition, home education in Romania is legally supported, to a certain extent, by The Romanian Constitution, which states that "parents or guardians are entitled ensures, according to their own beliefs, the education of minors under their responsibility " (Romanian Constitution - Article 29 (6)) and the Universal Declaration of Human Rights - Art.26, the right to education, with the important specification in par. (3): "Parents are entitled priority in choosing the type of education for their minor children. "Also, in 2010, Deputy Minister Carmen Axenie, told HotNews that the solution for reform education would be home education.

"The great center of our education is that it has no social vision or no, it doesn't allow the family to act an important role in child's education. We need a profound reform of Romanian education and homeschooling is an opportunity." (HotNews.ro, 2014, March 18)

Concerning the adoption of a clear law on homeschooling as an alternative form of education public education, supporters and practitioners concerned have begun to address implementing and regulating this system so that it is at hand any family who would like to choose for this s approach.

Presently, the Chamber of Deputies has a draft law on the legalization of home education as a distinct form of education in the administrative system Romanian. The law proposal sets out the conditions for good organization and the operation in which home education is to take place, the responsibilities of individuals involved in educating children, social workers and how they could be supported Ministry of Education.

In our country homeschooling is not accredited, however, due to umbrella schools in other countries, this alternative functions in Romania and as the years go by, one is noticed increasing number of students who are withdrawn from the traditional system and are being enrolled at an umbrella school to be able to do homeschooling. This movement allows parents to educate themselves their children, trying to and to be creative by promoting a personalized education. Homeschooling can have a curriculum structure or the child can learn what he wants every day. No day is the same, because the children to work on different projects according to their interests. Because 
homeschooling means more freedom, there are days when visiting a museum or zoo in order to learn about animals Preferred days are called school days because the child learns and develops their skills. There is an association called "Homeschooling Romania" where the founding president of this association is Gabriel Curcubet, who has 4 children and, together with his wife, has begun homeschooling in 2001, when their eldest son was 5 years old. He claims that through this alternative, children benefit of personalized and quality education, thanks to the advanced textbooks in the US. He sustains that the children benefit of the best educational programs and socialize more than in public schools. Costs are from $\$ 1,000$ per child for a school year. He also said that there are 200 families in Romania which enrolled their children in homeschooling. To have success in home education, there is no need for higher education, but rather a well-chosen curriculum and a well-motivated parent. The Homeschooling Romania Association supports this draft law, bringing it additions, modifications and constructive innovations to facilitate parents' involvement children in the educational-educational process. Experts in the field of education have made a comparison between the education received at the school public and homebased education, the results are shown in the table below:

Table no1. Adpated after Clay and Sally Clarkson, AHS România, (2004), "Educating the Whole Hearted Child"

\begin{tabular}{|c|c|}
\hline Education in public school & Education at home \\
\hline \multicolumn{1}{|c|}{ Public education concentrates on } & \multicolumn{1}{c|}{ Ede child is an individual. } \\
\hline $\begin{array}{l}\text { helping the child according to the home concentrates on } \\
\text { standards of the group so that he would } \\
\text { learn certain things in a certain time, in } \\
\text { certain ways without referring to } \\
\text { capacity or maturity. }\end{array}$ & $\begin{array}{l}\text { developing the whole person of a child, } \\
\text { is sensitive to his needs and his desires } \\
\text { to learn individually and give guidance } \\
\text { in growing in Christian maturity. }\end{array}$ \\
\hline $\begin{array}{l}\text { Learning structures are created with } \\
\text { accent on order, conformation, regime } \\
\text { and control. The formality is without } \\
\text { motivation, stifling the curiosity, } \\
\text { creativity and the desire for learning of } \\
\text { the child. }\end{array}$ & $\begin{array}{l}\text { Learning structures are created for } \\
\text { the thime and freedom unleash the } \\
\text { curiosity, creativity and the natural } \\
\text { desire for learning of the child. }\end{array}$ \\
\hline
\end{tabular}




\begin{tabular}{|c|c|}
\hline $\begin{array}{l}\text { The level of teaching is low so that } \\
\text { one wouldn't loose the lowest student of } \\
\text { the class. The high level students are } \\
\text { frustrated by the poor rhythm, the poor } \\
\text { students by the high rhythm, the } \\
\text { medium students by keeping the } \\
\text { teacher`s rhythm. The weak students are } \\
\text { stigmatized and the high students are } \\
\text { ostracized. }\end{array}$ & $\begin{array}{l}\text { The teaching aims everybody } \\
\text { within the homeschooling. The capacity } \\
\text { of teaching can vary without connotation } \\
\text { or subtle stigmatization. All the children } \\
\text { are progressing in their own rhythm and } \\
\text { according to their own level of learning } \\
\text { and motivation. Each child is treated as } \\
\text { individual without being compared to } \\
\text { the others. }\end{array}$ \\
\hline $\begin{array}{l}\text { The teacher can give limited } \\
\text { attention to each child in a class of 15- } \\
30 \text { children and is incapable to respond } \\
\text { to each child. The concentration is } \\
\text { prevented by several factors of attention } \\
\text { distraction in noisy large uncomfortable } \\
\text { classrooms or outside. }\end{array}$ & $\begin{array}{l}\text { The parent is capable to give to } \\
\text { each child the unlimited individual } \\
\text { attention in a one-to-one relationship and } \\
\text { is capable to answer to each child's } \\
\text { individual needs and interests. The } \\
\text { concentration is strengthened by the } \\
\text { ability of controlling and even be able to } \\
\text { eliminate attention distraction. }\end{array}$ \\
\hline $\begin{array}{l}\text { The student has to learn how to } \\
\text { please different teachers. The authority } \\
\text { relationships are unnatural and formal. }\end{array}$ & $\begin{array}{l}\text { Instinctively, the child desires to } \\
\text { please his parents. The authority } \\
\text { relationship is natural and loving. }\end{array}$ \\
\hline $\begin{array}{l}\text { The teacher is based on the } \\
\text { manuals and notebooks which are } \\
\text { without force and freshness. The } \\
\text { teachers is the authority; the school will } \\
\text { represent a necessary addiction and self- } \\
\text { reinforced by the teacher. }\end{array}$ & $\begin{array}{l}\text { The parent is free to choose the best } \\
\text { books and lively and fresh school } \\
\text { curriculum. The parents is an encourager } \\
\text { who is also learning; the child is taught } \\
\text { and it is expected from him to rely on his } \\
\text { own capacities and abilities. }\end{array}$ \\
\hline
\end{tabular}

\section{Research design and results}

The purpose of the research was to identify the extent to which homeschooling is known and spread as an educational alternative.

The main objective was to analyze how homeschooling takes place in families in our country, especially due to the fact that in Romania this alternative education is not legalized.

Another objective of the paper was to identify the advantages and disadvantages practicing homeschooling for both the child and the parents.

\section{a. Hypotheses}

Depending on the objectives we pursue, we formulated the following research assumptions:

Hypothesis 1: The children enrolled in homeschooling benefit of spending a good time with family, having a pleasant learning atmosphere, being protected from negative influences and studying topics according to their interests 
Hypothesis 2: Children registered in the homeschooling system develop lesser extent socio-relational skills due to lower contact with teachers and children.

Hypothesis 3: The more familiar and widespread is homeschooling as an alternative education, the more parents who enroll children in this education system would be encouraged and supported by family and friends.

Hypothesis 4: Families with a higher social level (higher education level) are more open to educational alternatives, and more willing to enroll their children homeschooling.

We used the questionnaire to collect the research data. It comprises 42 the actual questions, which were formulated in such a way as to be consistent with the theme of the research and by the answers that have been obtained, it is possible to measure the objectives and assumptions proposed in the paper. The questioning clearly delineated the question of the researched, they are clearly and concisely formulated, using a language accessible to the subjects and targeting certain aspects of the practice of this educational alternative, not responding to the answers.

The first questions were the factual ones: age, family type, environment residence, graduate level, number of children, monthly income of the family, situation professional. They have helped achieve one of the proposed objectives, namely, observing the social level of homeschooling practitioners, thus being able to analysis and proposed hypothesis, these families being more open to this alternative educational.

Thus, through the questionnaire, 23 parental families were surveyed, with more than $78 \%$ residing in the urban area. Of those who participated in this poll $78.3 \%$ were aged between $31-50$ years, $17.4 \%$ between $18-30$ years, and $4.3 \%$ over 50 years. $95.7 \%$ of all these participants have higher education and $69.6 \%$ of the total the parents interviewed also have pedagogical or psycho-pedagogical training.

Most of the surveyed families, namely $43.5 \%$, currently have only one child in their place two families with 3 children were present, reaching $30.4 \%$. The last two places are equally occupied by families with 2 children and those with more than 3 children, these reaching 13\%. From the poll, more than $52 \%$ of families were seen surveyed have monthly incomes of more than 4,000 ron, over $28 \%$ of income families monthly between 2000 4000 ron and 19\% have between 1000-2000 ron monthly income per month.

The closed-ended question number 39 helped me to see which is their own opinion about the financial level they would need to have in order to practice homeschooling. Thus, $47.6 \%$ believe the financial level is a hindrance to parents who want to join this educational system, 33.3\% disagree that itis an impediment, and 19\% have provided other explanations for this. From the point of view respondents' professional status $8.7 \%$ work 
part-time, around 39\% work full-time and over 50\%presents another professional situation.

To measure the goal of identifying the advantages and disadvantages of practicing homeschooling and analysis of the hypothesis of the benefits of homeschooling in the life of the child and his family and the disadvantages he has, we have used open and mixed, semi-open, semi-closed questions The questionnaire helped me to see what the reasons for choosing homeschooling were like educational alternative for their children. Thus, the national education system, the quality and its inefficiency presents the underlying reason which determine the parents to switch to another alternative. The desire to create a pleasant learning atmosphere, to educate the child holistically, to impregnate a good character to the child, without the negative influence, from morally point of view, are other reasons underlying the choice to do education at home. Other reasons were the freedom to choose a flexible program, the great variety and resources used, investing in the child a lot more than the state can do in a qualitative way, studying the materials that fit it child's.

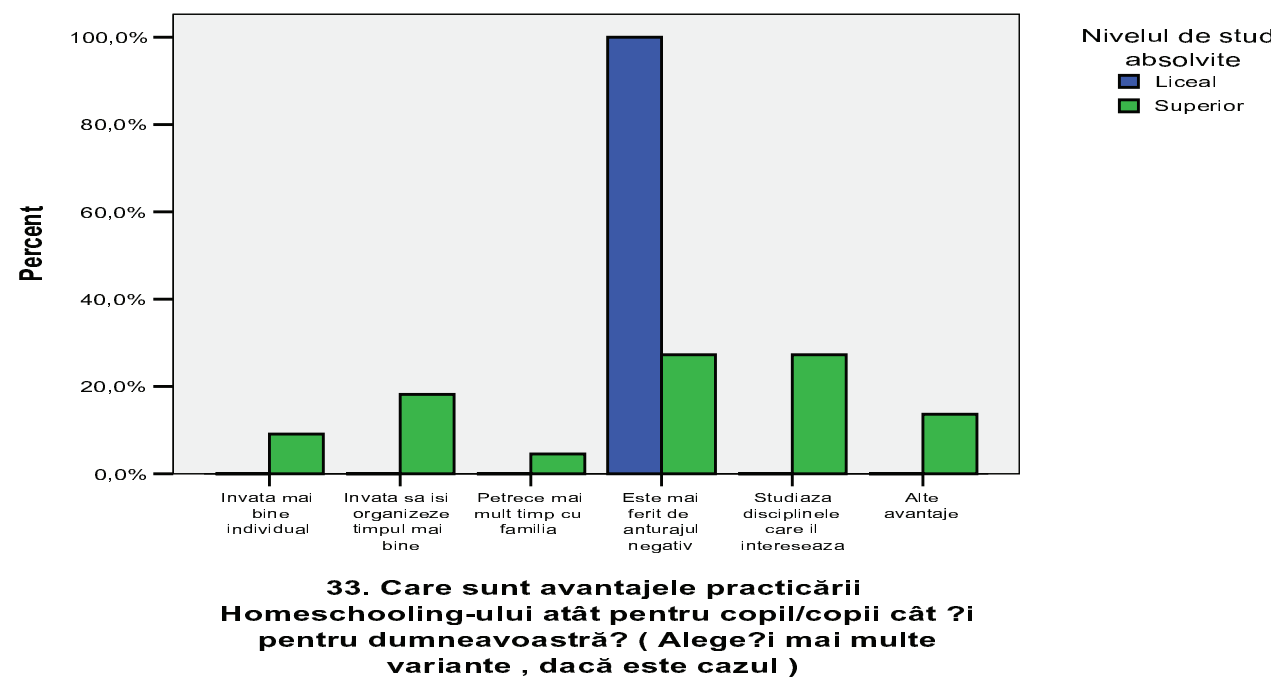

Figure no.1. Perceived Advantages of homeschooling 


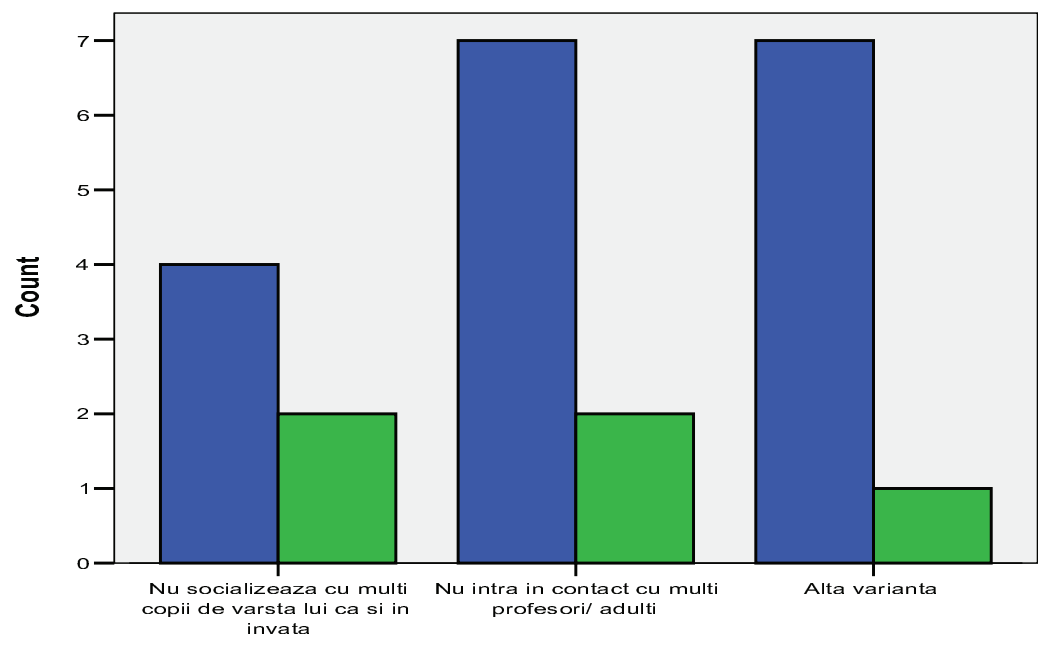

Mediul de reşedi 品 Urban

34. Care sunt dezavantajele practicării homeschooling-ului atât pentru copil/copii cât ?i pentru dumneavoastră?

\section{Figure no.2. Perceived disadvantages of homeschooling}

As can be seen in Figures 1, the analysis of questions 33-34 helps to see how parents perceive the advantages and disadvantages of practicing homeschooling. Advantages:

- Spending a longer time with the family (71.4\%),

- studying the subjects that interest the child (66.7\%),

- safer towards the negative influences $(61.9 \%)$,

- the child learns better individually

The opportunity to observe the socio-relational skills of the children involved in homeschooling revealed that $66.7 \%$ of parents thought their child was well related to others, $23.8 \%$ responded that the child interacts with a small group, and $9.5 \%$ said that the child relates well but conflicts with certain children. Most parents, $71.4 \%$ saw the children very sociable, and $28.6 \%$ consider their child sociable to a certain extent. The biggest perceived drawback of homeschooling is that the child does not come in contact with many teachers or adults and does not socialize with many children of his age, as would be the case in formal national education.

The question number 6, "To what extent have you been supported by the family and? Friends, "reflects the small spread of homeschooling and little support in the country. Thus, the majority of over $33 \%$ were sustained to a small extent by the family and boyfriends to enroll the child in this system. 
Over $27 \%$ were not supported at all, $22 \%$ received support from family and friends to some extent and only $16.7 \%$ have been strongly encouraged by the family and friends to enroll the child in the homeschooling system. Given the general situation in our country in terms of the system of thinking and opening up to the new, we can say the results to this question reflects with enough accuracy the level of the mentalities in our country. Question number 3 has helped us to find out how these families have learned about this educational alternative. Thus, it can be noticed that the majority of the families, $27.3 \%$, learned of homeschooling through the internet and $22.7 \%$ were informed by parents who have children already enrolled in this education system. $18.2 \%$ learned about homeschooling from social media and $13.6 \%$ were informed of by other families and specialized books have informed. The same place, $13.6 \%$ occupy families that have been informed from other sources, such as the church. Questions 40 and 41 have reached the issue of legalization, $90.9 \%$ of interviewees wanting to legalize homeschooling in Romania. We mentioned some of the arguments in favor of the legalization of homeschooling as a viable option: Romania would benefit of better trained and educated youngsters, more parents would have the courage to do homeschooling with their children, so that our children can only study what is really important. In their opinion home education is the most effective and safest educational option, the child has the freedom to be focused on the subjects that passionate him/her and develop him/ herself better from an emotional point of view. As parents we do not have to deal with the "corruption system" that exists in our country's educational system. Here are some arguments for which the interviewed parents would promote homeschooling: practically-efficient-flexible, no one can educate your child with more dedication and interest than you, the education of the children is done according to their abilities, control freedom-economy, quality of teaching ( by tutorial filter), child happiness (low level of stress, higher selfesteem), opportunities to grow in their own pace, balanced study-flexible program 
17. Ce discipline studiază copilul dumneavoastră? Alegeți mai multe răspunsuri

22 de răspunsuri

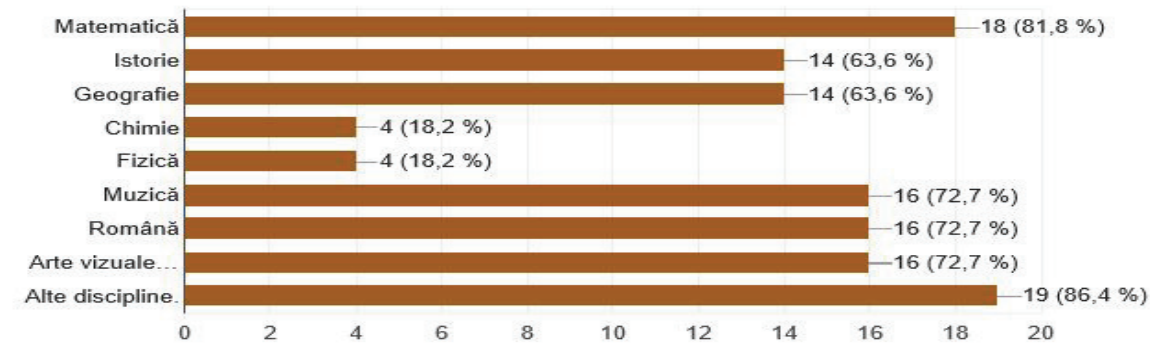

18. La ce activitați participa copilul dumneavoastră? Alegeți mai multe variante dacă e cazul

22 de răspunsuri

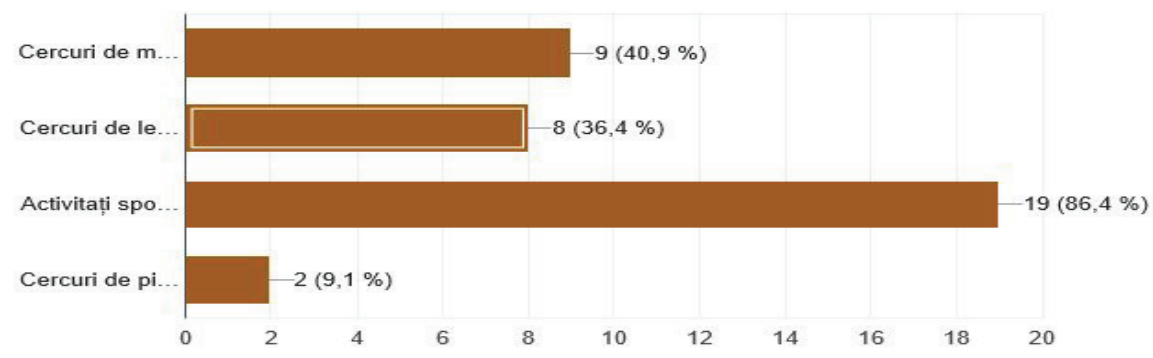

Figure no.3 - Topics and activities studied by the homeschooling enrolled children

As it can be seen from Figure 3, referring to the question about what subjects are studied, $86.4 \%$ of interviewed parents prefer for their children to study other disciplines than those we find in public school. But we noticed that $81.8 \%$ nevertheless focus on Math knowledge, and Romanian language. Music and the visuals arts rank at third place with a $72.7 \%$ share. We also noticed that the general knowledge of history and geography are considered important, reaching a percentage of $63.6 \%$. Chemistry and physics occupied the last place in parents' preference with only $18.2 \%$. Sport is by far the most preferred recreational activity $(86.4 \%)$, followed by music $(40.9 \%)$ and reading (36.4\%), a small interest $(9.1 \%)$ being given to the painting.

In the following rows, you can see the schedule of a child practicing homeschooling. 


$$
\begin{aligned}
& \text { 8:00 }-8: 30=\text { morning routine } \\
& \text { 8: } 30-9.00=\text { breakfast } \\
& \text { 9.00 }-10.00=\text { devotional time } \\
& 10.00-10.50=\text { English } \\
& 10.50-11.00=\text { Break } \\
& 11.00-11.50=\text { Mathematics } \\
& 11.50-12.00=\text { Break } \\
& \text { 12:00 }-12: 50=\text { English } \\
& \text { 12: } 50-13: 20=\text { Lunch } / \text { Lunch } \\
& \text { 13:20 }-14: 30=\text { Art activities } \\
& \text { 14:30 }-16: 00=\text { PC games }
\end{aligned}
$$

We have noticed that the program of children educated at home is a flexible one, the subject matter studied are choose according to the interests of the child, the pace of learning is also choosing by the child. From the received answers, it could be noticed that there are not fixed hours for studying certain subjects as they exist in mass education, but there is a certain program on dedicated to intense study. Thus, in most of the programs presented, we have noticed that the time spent on studying disciplines is in the morning, with pauses, depending on the child's pace. Although, apparently, everything is left to the latitude of the child, we noticed that parents are concerned about maintaining a balance between the study of disciplines traditionally included in national curriculum (such as mathematics, Romanian and foreign languages) and between interests-based activities (such as the arts, sports, reading, walks, visits to various places). Biblical study is also very important for many families. Another important thing is the fact that these children are involved in household activities (such as cleaning, shopping, meal preparation, guest reception) and through which they are developing their food manners, abilities, skills, character.

\section{Conclusions}

According to the survey we have conducted we can say that homeschooling is still not well known spread as an educational alternative. We have noticed that parents who already practice this education system faces the prejudices of those around them, not benefitting by the support of family or close friends. Sometimes, due to this thinking system, parents do not even dare to say that they educate their own children because they are afraid that they will be judged. An explanation of the fact that homeschooling is not yet spread or accepted is the fact that there are few communities or associations of homeschooling families in our country or practitioners are unaware of the existence of such communities. Perhaps, if practicing parents from the same town would know and meet regularly for common activities, they would find the mental and soul support they need in 
order to go forward with this educational alternative. Another big impediment for homeschooling to be practiced in our country is that it is not legally recognized, and therefore none is grantee kind of certificates for children who have been enrolled in this education system. The main benefit of practicing home schooling in parent's perception, is the fact that the children benefit from a safe place, a pleasant learning atmosphere, a quality time spent with parents who get involved both in child's education and leisure activities. The benefits of homeschooling also lie in the fact that these children are protected from negative influences, they are raised within the moral framework desired by their parents and they have the opportunity to study the disciplines they are more interested in. By being engaged in various domestic activities they develop their skills, talents and character. But, evaluating the results of questions about the relationship of children with other children and with adults, we found that a disadvantage of homeschooling is that exist the danger for these children to develop a lower level of socio-relational skills. In order to prevent that the parents should encourage the children to practice various socio-educational activities in the open air or in different locations.

We observed that families who have enrolled their children in homeschooling have higher education level, they are assuming a different kind of costs for their children 'education. That is why we believe that families of a higher social level are more open to alternatives and are more willing to enroll their children in homeschooling. We appreciate and respect the parents who practice this alternative, especially if the results are adequate. for the children We think that parents who educate their children at home need to have communication skills, management abilities and be a gentle, patient, creative and diligent person for this very important job: educating the child, developping a character that will reflect the received education.

\section{Referrences}

Bran, C., (2012), Reference points for an efficient learning, Editura Universităţii ,Aurel Vlaicu” Arad

Bran, C., (2004), The influence of teacher's personality over learning methodology, Editura Mirton

Clarkson, Clay and Sally, AHS România,(trad.), (2004), "Educating the Whole Hearted Child"

4.The Constitution of Romania, available at http://www.ucv.ro/pdf/site/constitutia romaniei.pdf, logged in 10.03.2017

HotNews.ro available at http://www.hotnews.ro/stiri-esential-6953744interviu-deputatul-carmen-axenie-despre-invatamantul-domiciliuhomeschooling-statul-economiseste-niste-bani-iar-unii-parinti-vormultumiti-ascultat-cerinta.htm, logged in 23.10.2017 